\title{
Evaluation of Antimicrobial Activity of Root Extracts of Abitulon indicum
}

\author{
Department of Botany, Andhra University, Visakhapatnam 530003 (A.P.) \\ India; lagudu3@gmail.com (*correspondingauthor)
}

Aniel Kumar OWK, Krishna Rao MORTHA, Mutyala Naidu LAGUDU*

\begin{abstract}
Antimicrobial activity of Abitulon indicum roots was studied against seven pathogenic bacteria and three fungal strains by agar well diffusion method. Antimicrobial activity was recorded for hexane, chloroform, methanol, ethanol and aqueous extracts. Alcohol (ethanol and methanol) extracts exhibited the highest degree of antimicrobial activity compared to aqueous, chloroform and hexane extracts. Pseudomonas aeruginosa was turned out to be the most susceptible bacterium to the crude root chemical constituents, using the standard Tetracycline and Clotrimazole. Minimum inhibition concentration values of hexane, chloroform, methanol, ethanol and aqueous extracts were determined by the agar dilution method and ranged between 62.5 and 1,000 $\mu \mathrm{g}$. The study suggested that the root extracts possess bioactive compounds with antimicrobial activity against the tested bacteria and fungi, revealing a significant scope to develop a novel broad spectrum of antimicrobial drug formulation from Abitulon indicum.
\end{abstract}

Keywords: alcohol extract, bioactive compounds, microorganisms, MIC

\section{Introduction}

Plants represent a valuable source of natural products and have the capacity to produce a large number of organic photochemicals, such as secondary metabolites, which serve as plant self defense mechanisms against pests and pathogens. Natural products have played an important role in treating and preventing human ailments. It is estimated that over $50 \%$ of all drugs (and their derivatives and analogs) in clinical use, are higher plant derived natural products. According to the World Health Organization (WHO), about $80 \%$ of the people in developing countries still rely on traditional medicine for their primary health care and about $85 \%$ of such medicines involve the use of plant extracts. According to recent estimates from WHO, more than 3.5 billion people in the developing world rely on plants as source of medicine for various ailments. Over 20,000 plants have medicinal values and many plants are yet to be explored for their potential. In addition, many of the existing synthetic drugs cause various side effects. Hence, drug development from plant based compounds could be useful in meeting the demand for newer drugs with minimal side effects (Srivastava et al., 2000).

A. indicum L. (Indian Abutilon, Indian mallow) is a small shrub in the Malvaceae family, native to tropic and subtropical regions (Kirtikar and Basu, 1980). It is often used as a medicinal plant and widely used in pharmacological disorders and ailments. Traditionally, it is used in inflammation, piles, gonorrhea treatment and as an immune stimulant. The root and bark are used as a diuretic, anthelmintic, pulmonary sedative and for fever release (Kashmiri et al., 2009). The root is used for diuretic disorders and can be taken for the relief of hematuria (Thongsiri, 2001). It is also effective in the treatment of leprosy. The root infusion is prescribed as a cooling medicine (fever) and is considered useful in strangury and haematuria.
The root is true, $1.2-1.5 \mathrm{~cm}$ in diameter, cylindrical with smooth surface, yellow in color with strong fragrance and saltish in taste. The antimicrobial activities of the crude extracts of leaves (Prabahar et al., 2009), whole plant (Geda et al., 1978; Naqvi et al., 1991), flowers (Mateen et al., 2011), roots (Bhakuni et al., 1971; Valsaraj et al., 1997) were studied, but so far the literature on antimicrobial activity of ethanol and benzene extracts of $A$. indicum roots is scarce.

\section{Materials and methods}

\section{Chemicals, media and antibiotics}

The organic solvents (hexane, chloroform, methanol, ethanol and dimethyl sulphoxide -DMSO), were obtained from Rankem company, India. Nutrient broth, Nutrient agar and Saboraud dextrose agar were obtained from Hi-media, Mumbai, India. The antibacterial agent Ciprofloxacin was obtained from Axiom Laboratories Ltd., India.

\section{Root collection}

The roots of $A$. indicum $\mathrm{L}$. were collected from Sudikonda forest, East Godavari district, Andhra Pradesh. The specimen was authenticated by Prof. Vatsavaya S. Raju, Plant Systematics Lab, Kakatiya University, Warangal, and voucher specimen was deposited in the Herbarium, Botany department (BDH), Andhra University, Visakhapatnam.

\section{Root extract}

The dugout roots were cleaned and dried in shade (25-28 $\left.{ }^{\circ} \mathrm{C}\right)$ for a month. The dried roots were grounded using a mechanical grinder. Sequential extraction was done using hexane, chloroform, followed by methanol and finally 
ethanol. The filtrates were concentrated by removing the solvents under reduced pressure at $40{ }^{\circ} \mathrm{C}$ using a rotary evaporator. The concentrated crude extracts were labeled and stored at $4{ }^{\circ} \mathrm{C}$ (Rao et al., 2010).

Simultaneously, the aqueous extract of the root was prepared by adding boiled water to the root obtained powder in a beaker, on water bath, with occasional stirring, for $4 \mathrm{hrs}$. The aqueous extract was then filtered and reduced under pressure. At the time of testing, known quantity of crude extract $(100 \mathrm{mg} / \mathrm{ml})$ was dissolved in DMSO.

\section{Microbial strains and growth conditions}

Seven bacterial strains namely Bacillus subtilis (MTCC 2763), Escherichia coli (MTCC 2960), Klebsiella pneumoniae (MTCC 4032), Pseudomonas aeruginosa (MTCC 6642), Proteus vulgaris (MTCC 1771), Staphylococcus aureus (MTCC 7443), Streptomyces pneumoniae (MTCC 1935), as well as three fungal strains Aspergillus niger (MTCC 4360), Candida albicans (MTCC 4748) and Saccharomyces cerevisiae (MTCC 4742) were procured from IMTECH, Chandigarh, India. Broth and agar were prepared according to the manufacturer's instructions.

Before testing, the bacterial suspension was transferred to nutrient broth and cultured at $37{ }^{\circ} \mathrm{C}$. Inoculates were prepared by adjusting the turbidity of the medium to match the $0.5 \mathrm{MC}$ farland standard. The fungal cultures were maintained on Saboraud dextrose agar, incubated at $25^{\circ} \mathrm{C}$ for 4 days. The fungal growth was harvested and washed with sterile normal saline and finally suspended in $100 \mathrm{ml}$ of sterile normal saline; the suspension was stored in refrigerator till used.

\section{Determination of antimicrobial activity}

Antibacterial and antifungal activity of Abitulon indicum L. root extracts were determined using agar well method (Owk et al., 2014). For susceptibility test, $100 \mu \mathrm{l}$ of inoculums, equivalent to $10 \mathrm{CFU}$, were mixed with $6 \mathrm{ml}$ of nutrient agar (to ensure even distribution of bacteria) and poured immediately into the sterile petri plates. The petri plates were left for 10 minutes in order for agar to solidify. A sterilized $6 \mathrm{~mm}$ borer was used to make wells in the centre of the divided areas. About $50 \mu \mathrm{l}$ of each extract were then pipette into the wells. Petri plates with bacteria and test extracts were incubated at $37^{\circ} \mathrm{C}$ for $16-18 \mathrm{hr}$ after which the inhibition zone (IZ) was measured using an antibiotic zone reader scale (HiAntibiotic ZoneScale-c).

For the antifungal activity, the same method as for bacteria was adopted and Saboraud dextrose agar was used. The inoculated medium was incubated at $25^{\circ} \mathrm{C}$ for two days for Candida albicans, Saccharomyces cerevisiae and three days for Aspergillus niger. About $500 \mu \mathrm{g}$ of clotrimazole were dissolved in $1 \mathrm{ml}$ of sterile de ionized water. About $10 \mu \mathrm{l}$ of $0.5 \mathrm{mg} / \mathrm{ml}$ clotrimazole (equivalent to $5 \mu \mathrm{g}$ dose) and $10 \mu \mathrm{l}$ of DMSO were pipette into wells. For bacteria, multidrug antibiotic disc was used (Axiom Laboratories Ltd., India). Each experiment was conducted in triplicates and diameter of the IZ surrounding each well was recorded.

The extracts that exhibited IZ were subjected to minimum inhibition concentration (MIC) assay by using serial two-fold dilution (Krishna Rao et al., 2013). A quantity of $0.6 \mathrm{~g}$ of each extract was dissolved in $300 \mathrm{ml}$ sterile nutrient broth which yields initial concentration of 2,000 $\mathrm{\mu g} / \mathrm{ml}$. Subsequently, two-fold serial dilution was made from the stock to obtain 1,000, 500, 250, 125 and $62.5 \mathrm{\mu g} / \mathrm{ml}$ concentrations. One $\mathrm{ml}$ of standardized inoculum of each test organism was introduced into each extract nutrient broth mixture and then incubated at $37{ }^{\circ} \mathrm{C}$. The lowest concentration inhibiting growth was regarded as the MIC of the extracts. For the fungi, the inoculated medium was incubated at $25^{\circ} \mathrm{C}$ for two (C. albicans, $S$. cerevisiae) or three (A. niger) days.

\section{Statistical analysis}

Each experimental data from triplicates was subjected to one way ANOVA using Minitab version 15. A significant level of 0.05 was used for all statistical analyses.

\section{Results and discussions}

The antimicrobial activity of the five different solvent extracts of $A$. indicum revealed that the ethanol extract had significant activity against all the tested microorganisms, followed by methanol extract, while the chloroform and hexane extracts possessed moderate activity and the aqueous extract had the weakest activity. The results of the present study were significant at level of $\mathrm{p}>0.05$.

Ethanol extract exhibited the highest inhibitory zone against $P$. aeruginosa, followed by $P$. vulgaris, while methanol extract exhibited the maximum inhibitory effect against $E$. coli and $S$. griesus, and hexane extract showed the high zone of inhibition against $K$. pneumoniae and $P$. aeruginosa. The chloroform and aqueous extracts showed maximum inhibitory zone against $S$. cerevisiae (Table 1). Ethanol extract evinced significant antimicrobial activity with standard antibiotics tetracycline and clotrimazole.

From the MIC values (Table 2), it was observed that $P$. aeruginosa, $P$. vulgaris and $A$. niger were the least sensitive to ethanol extract at concentration of $62.5 \mu \mathrm{g} / \mathrm{ml}$, whereas methanol extract was found to have the smallest MIC value against $E$. coli and $S$. griesus.

Alcohol extract of $A$. indicum roots produced the most consistent level of inhibition of microbial growth. The results indicated that most of the active constituents responsible for exerting antimicrobial action are expected to be soluble in alcohol. The preliminary phytochemical investigation revealed the presence of alkaloids, amino acids, anthraquinone, carbohydrates, cardiac glycosides, flavonoids, glycosides, phenols, saponins, steroids, tannins and terpenoids (Table 3). The combined activities of these secondary metabolites produced a synergic effect, thus increasing the antimicrobial potency of alcohol extracts of $A$. indicum.

Hexane and chloroform extracts had low antimicrobial effect on the tested organisms. This may be due to the presence of only few compounds extracted into the solvent with not enough inhibitory activity against tested pathogens.

Prabahar et al. (2009) reported that ethanol extracts of $A$. indicum leaves showed antimicrobial activity against Gramnegative organisms $P$. aeruginosa, $P$. vulgaris, E. coli, Shigella sonnei and Gram-positive organisms such as B. subtilis, $B$. megatherium, $S$. leuka, $S$. aureus, while ethanol extracts of flowers was found to be effective against $S$. aureus, $P$. aeruginosa, 
162

Table 1. Antimicrobial activity of different extracts of Abitulon indicum roots

\begin{tabular}{|c|c|c|c|c|c|c|c|}
\hline \multirow{2}{*}{$\begin{array}{l}\text { Organism } \\
\text { tested }\end{array}$} & \multicolumn{4}{|c|}{$\begin{array}{c}\text { Zone of inhibition } \\
\text { (in } \mathrm{mm}) \pm \mathrm{SE}\end{array}$} & \multicolumn{3}{|c|}{$\begin{array}{c}\text { Standard drugs/ } \\
\text { controls }\end{array}$} \\
\hline & $\begin{array}{c}\text { Methanol } \\
\text { extract }\end{array}$ & $\begin{array}{c}\text { Ethanol } \\
\text { extract }\end{array}$ & $\begin{array}{c}\text { Aqueous } \\
\text { extract }\end{array}$ & $\begin{array}{c}\text { Chloroform } \\
\text { extract }\end{array}$ & Hexane extract & $\begin{array}{l}\text { Tetracyclin/ } \\
\text { clotrimazole }\end{array}$ & DMSO \\
\hline B. subtilis & $19 \pm 0.6$ & $20 \pm 0.7$ & $14 \pm 0.1$ & $16 \pm 0.0$ & $12 \pm 0.4$ & $18^{\mathrm{T}}$ & $\mathrm{Nil}$ \\
\hline E. coli & $20 \pm 0.6$ & $18 \pm 0.6$ & Nil & $15 \pm 0.6$ & $15 \pm 1.1$ & $22^{\mathrm{T}}$ & $\mathrm{Nil}$ \\
\hline K. pneumoniae & $18 \pm 0.1$ & $17 \pm 0.2$ & $18 \pm 0.0$ & $14 \pm 1.5$ & $16 \pm 0.2$ & $24^{\mathrm{T}}$ & Nil \\
\hline$P$. aeruginosa & $17 \pm 0.4$ & $24 \pm 0.1$ & $12 \pm 0.5$ & $16 \pm 0.3$ & $16 \pm 0.2$ & $23^{\mathrm{T}}$ & Nil \\
\hline P. vulgaris & $18 \pm 1.4$ & $22 \pm 0.5$ & Nil & $12 \pm 0.2$ & $14 \pm 0.5$ & $22^{\mathrm{T}}$ & Nil \\
\hline S. aureus & $19 \pm 0.0$ & $18 \pm 0.4$ & $\mathrm{Nil}$ & $16 \pm 0.0$ & $14 \pm 0.4$ & $24^{\mathrm{T}}$ & Nil \\
\hline S. griesus & $20 \pm 0.3$ & $20 \pm 0.1$ & Nil & $14 \pm 0.2$ & $12 \pm 0.4$ & $22^{\mathrm{T}}$ & Nil \\
\hline A. niger & $16 \pm 0.5$ & $19 \pm 0.0$ & $10 \pm 0.3$ & $\mathrm{Nil}$ & Nil & $18^{\mathrm{C}}$ & $\mathrm{Nil}$ \\
\hline C. albicans & $14 \pm 0.2$ & $16 \pm 0.3$ & $20 \pm 0.6$ & $12 \pm 0.4$ & $13 \pm 0.0$ & $23^{\mathrm{C}}$ & Nil \\
\hline S. cerevisiae & $19 \pm 1.1$ & $21 \pm 0.3$ & $21 \pm 0.7$ & $18 \pm 0.5$ & $12 \pm 0.4$ & $20^{\mathrm{C}}$ & Nil \\
\hline
\end{tabular}

All the values of inhibitory activity for the extracts tested were significant at 0.05 levels

Table 2. MIC obtained with different extracts of Abitulon indicum roots

\begin{tabular}{|c|c|c|c|c|c|}
\hline $\begin{array}{l}\text { Organism } \\
\text { tested }\end{array}$ & $\begin{array}{c}\text { Methanol } \\
\text { extract }\end{array}$ & $\begin{array}{c}\text { Ethanol } \\
\text { extract }\end{array}$ & $\begin{array}{c}\text { Aqueous } \\
\text { extract }\end{array}$ & $\begin{array}{c}\text { Chloroform } \\
\text { extract }\end{array}$ & $\begin{array}{r}\text { Hexane } \\
\text { extract }\end{array}$ \\
\hline B. subtilis & 250 & 250 & 1,000 & 1,000 & $>1,000$ \\
\hline E. coli & 62.5 & 500 & $>1,000$ & 1,000 & 1,000 \\
\hline K. pneumoniae & 500 & 500 & 500 & 1,000 & 125 \\
\hline P. aeruginosa & 500 & 62.5 & $>1,000$ & 500 & 125 \\
\hline P. vulgaris & 500 & 62.5 & $>1,000$ & 1,000 & 1,000 \\
\hline S. aureus & 250 & 500 & $>1,000$ & 1,000 & 1,000 \\
\hline S. griesus & 62.5 & 250 & $>1,000$ & $>1,000$ & $>1,000$ \\
\hline A. niger & 1,000 & 62.5 & $>1,000$ & $>1,000$ & $>1,000$ \\
\hline C. albicans & 1,000 & 1,000 & 250 & 1,000 & $>1,000$ \\
\hline S. cerevisiae & 250 & 125 & 125 & 500 & $>1,000$ \\
\hline
\end{tabular}

Table 3. Preliminary phytochemical constituents of Abitulon indicum root extracts

\begin{tabular}{|c|c|c|c|c|}
\hline $\begin{array}{l}\text { Phytochemical } \\
\text { constituents }\end{array}$ & $\begin{array}{c}\text { Chloroform } \\
\text { extract }\end{array}$ & $\begin{array}{c}\text { Methanol } \\
\text { extract }\end{array}$ & $\begin{array}{c}\begin{array}{c}\text { Ethanol } \\
\text { extract }\end{array} \\
\end{array}$ & $\begin{array}{c}\text { Aqueous } \\
\text { extract }\end{array}$ \\
\hline Alkaloids & + & + & + & + \\
\hline Aminoacids & + & + & + & + \\
\hline Anthraquinone & - & - & - & - \\
\hline Carbohydrates & - & + & + & + \\
\hline Cardiac glycosides & + & + & + & - \\
\hline Flavonoids & + & + & + & + \\
\hline Glycosides & + & + & + & - \\
\hline Phenols & - & + & + & + \\
\hline Saponins & + & + & + & + \\
\hline Steroids & - & + & + & - \\
\hline Tanins & - & + & + & + \\
\hline Terpenoids & - & - & + & - \\
\hline
\end{tabular}

Salmonella typhi, S. paratyphi, P. vulgaris, K. pneumonia, E. coli, Shigella sonnei (Mateen et al., 2011). These are in accordance with the present study results, as ethanol extract of roots showed antimicrobial activity against $B$. subtilis, E. coli, K. pneumonia, $P$. aeruginosa, $P$. vulgaris, $S$. aureus, $S$. griesus, A. niger, $C$. albicans and $S$. cerevisiae. Poonkothai (2006) reported the ethanol and chloroform leaf extract showed activity against $B$. subtilis, $S$. aureus, $K$. pneumonia, $P$. aeruginosa, $E$. coli, $S$. typhi, while Gurumurthy et al. (2011) stated petroleum ether, chloroform and methanol extracts showed high antimicrobial activity against $S$. aerus, $P$. aureus, $K$. pneumoniae and less activity found against E.coli.

The finding of the present study also showed methanol, ethanol, aqueous, chloroform and hexane extracts were efficient against all tested microorganisms except $E$. coli $P$. vulgaris, $S$. aureus, $S$. griesus for aqueous extract and $A$. niger for both chloroform and hexane extracts of $A$. indicum roots.

\section{Conclusions}

A. indicum is already considered as medicinal plant. The plant is said to be a source of many bioactive principles acting against some human ailments; the root extracts analyzed hereby exhibited high degree of antimicrobial activity against all tested bacteria and fungal strains. The present study also suggested that root posses' bioactive compounds responsible for exerting antimicrobial action against infectious diseases caused by bacteria and fungi. Therefore, it is concluded that alcohol extracts of $A$. indicum roots brings to light the scope to develop a novel broad spectrum of antimicrobial drug formulation.

\section{Acknowledgements}

We are grateful to UGC-SERO, Hyderabad for providing FDP Teacher fellowship and Prof. Vatsavaya S. Raju, Kakatiya University, Warangal, for constructive suggestions. 


\section{References}

Bhakuni DS, Dhar ML, Dhar MM, Dhawan MN, Gupta B, Srimal RC (1971). Screening of Indian Medicinal Plants for biological activity Part III, Ind J Exper Biol 9:91-102.

Geda A, Jain PK, Bokardia MM (1978). Antimicrobial activity of some Indian essential Oils. Acta Cienc Indica 4:248-251.

Gurumurthy H, Ramachandra YL, Rai SP (2011). In-Vitro antibacterial study on leaf extracts of Abutilon indicum Linn. Electronic Journal of Environmental, Agricultural and Food Chemistry 10(2):1892-1896.

Kashmiri MA, Yasmin S, Ahmad M, Mohy-ud-Din A (2009). Characterization, compositional studies, antioxidant and antibacterial activities of seeds of Abutilon indicum and Abutilon muticum grown wild in Pakistan. Acta Chim Slov 56:345-352.

Kirtikar KR, Basu BD (1980). Indian medicinal plants, 2nd Ed, Vol 1., Bishen Singh, Mahendra Pal Singh, India pp 314-15.

Krishna Rao M, Aniel Kumar O, Mutyala Naidu L (2013). In Vitro Antimicrobial activity of Alangium salvifolium L. roots. IJARST 2(2):88-91.

Mateen A, Suresh PVK, Ahmed P (2011). Evaluation of antibacterial activity of cuscuta reflexa and Abutilon indicum. Int J Pharma Bio Sci 4(2):B355-B361.
Naqvi S, Khan MSY, Vohora SB (1991). Anti-bacterial, anti-fungal, and anthelmintic investigations on Indian medicinal plants. Fitoterapia 62:221-228.

Owk AK, Mortha KR, Lagudu MN (2014). Evaluation of antimicrobial activity of chemical constituents of Achyranthes aspera L. roots against human pathogens. Indian Journal of Natural Products and Resources 5(3):278-281.

Poonkothai M (2006). Antibacterial activity of leaf extract of Abutilon indicum. Ancient Science of Life 25(1-2):39.

Prabahar AE, Thangabalan B, Chavala A, Kumar SS, Kathiravan M, Karthikeyan R (2009). Antibacterial activity of various extracts of Abutilon indicum (L.) sweet leaves. Journal of Pharmacy Research 2(8):1324-1325.

Rao KR, Kumar OA, Naidu LM (2010). Antibacterial evaluation of snake weed (Euphorbia hirta L.). Journal of Phytology 2(3):08-12.

Srivastava A, Shukla YN, Kumar S (2000). Recent development in plant derived antimicrobial constituents: a review. Journal of Medicinal and Aromatic Plant Sciences 22(2-3):349-405.

Thongsiri P (2001). Anti-diabetic activity of Thai medicinal herbs in normal and streptozotocin-diabetic rats (MS thesis). Nakorn Pathom: Faculty of Graduate studies, Mahidol University, Thailand.

Valsaraj R, Pushpangadan P, Smitt UW, Adsersen A, Nyman U (1997). Antimicrobial screening of selected medicinal plants from India. Journal of Ethnopharmacology 58(2):75-83. 